\title{
STRENGTHENING ISLAMIC BANKING SERVICES IN INDONESIA THROUGH BLOCKCHAIN TECHNOLOGY: THE ANP- STEP APPROACH \\ Rahmayati \\ rahmayati@,umsu.ac.id
}

\begin{abstract}
The purpose of this research is to examine so that financial services in Islamic banking are strong through digitization of blockchain applications that provide benefits to Islamic financial technology (fintech), through aspects of Security, Transparency, Efficiency, Permanent (STEP). The research data were obtained from in-depth interviews and then completed questionnaires from respondents who had been determined by using purposive sampling technique. The data analysis of this study used the Analytical Network Process (ANP) method with Super Decision software through the STEP aspect. The results show that the blockchain technology adopted by Islamic banking in Indonesia can strengthen financial services by using the STEP aspect, which is an integral part of facilitating the process, access, and proving the role of blockchain in Islamic banking business products.
\end{abstract}




\section{Introduction}

The development of fintech services is so innovative and varied, such as crowdfunding, mobile payments, and money transfer services, causing a revolution in the startup business. With crowdfunding, you can get funds from all over the world easily, even from people you have never met, even though fintech also allows global or international money transfers. Fintech also has an important role in changing consumer behavior and expectations, including being able to access data and information anytime and anywhere and to uniform large and small businesses so that they tend to have high expectations even for small businesses that have just been built.(Irma Muzdalifa, Inayah Aulia Rahma, 2018).

Financial Technology (FinTech). The financial technology (fintech) industry is a method of financial services that is gaining popularity in today's digital era. And digital payments are one of the most developed sectors in the fintech industry in Indonesia. This sector is then the most expected by the government and society to encourage an increase in the number of people who have access to financial services. The potential for the digital economy in Indonesia is enormous and it is important to develop it.(Wibowo, 2016).

Financial technology (fintech) is a new form of business that involves the power of technology and digital devices to create convenience in financial transactions. In Indonesia, Fintech is developing in various sectors, from payment startups, lending, personal finance, retail investment, crowdfunding, remittances, financial research, and others. Although some people say that Fintech is a new phenomenon, namely the phenomenon of dispruptive innovation in the financial services industry, it is potential

market and technological advances will continue to support the development of Fintech. Especially with the strengthening of regulations from Bank Indonesia (Regulation No.18 / 40 / PBI / 2016 on the emergence of payment transaction processes) and the Financial Services Authority Regulation (POJK No.77 / POJK.01 / 2016 concerning Information Technology-Based Borrowing and Lending Services) which regulating Fintech in Indonesia(Wulandari, 2017).

There are two main reasons for the emergence of fintech companies. First, the global financial crisis of 2008, clearly showed consumers the shortcomings of the traditional banking system that caused the crisis. Second, the emergence of new technologies that help provide mobility, ease of use (visualization of information), speed and lower costs of financial services(Anikina et al., 2016). 


\section{Rahmayati}

Strengthening Islamic Banking Services In Indonesia Through Blockchain Technology: The ANP- STEP Approach

Research conducted on a survey of 10,131 people across Australia, Canada, Hong Kong, Singapore, UK and the US on the use of fintech products revealed that only 15.5 percent of all respondents used non-bank services and it is hoped that this number will increase rapidly in the future. . 25 percent of respondents indicated that they use non-banking services very frequently and in normal practice they use 2-3 non-banking products. This data shows that banking service users are also potential customers of fintech services(Saksonova \& KuzminaMerlino, 2017).

The business model and technology infrastructure of the bank are based on this technology to make efficiency, for example, opening branches is expensive, manual processes, and marketing. In addition, banks also conduct head to head competitions with other banks in terms of margin or profit. From this illustration, if banks fail to adapt to Fintech, they may lose customers, especially customer segments in the future. So that concrete actions must be taken by bank management to ensure the survival of the bank in this Fintech era(Susanne Chishti \& Janos Barberis, 2016).

Fintech will help Islamic banks to reach the widest range of customers to transact in Islamic banks so as to promote the value of Sharia and Islamic bank ethics. The next step is to help customers use the Islamic banking application that can be downloaded by customers to carry out real-time online banking transactions, especially later in the financing segmentation. This action will lead to more online systems by customers and increase the market share of Islamic banks. The direct impact is reducing costs to customers and accelerating the service process for submitting financing products at Islamic banks.

The biggest obstacle to developing Islamic financial technology is the lack of trained human resources and clear policies from the government, to develop the right ecosystem for the development of Islamic fintech in the country, the government must bring the right regulations, educational intuition must bring good research and provide trained personnel. The success of Islamic fintech can be attributed to the number of financial service areas where FinTech can be linked, for example, it can be linked to cryptocurrency, blockchain and other areas such as cross-border payments.(Rabbani et al., 2020).

The presence of blockchain in Indonesia is not very common, but when compared to other countries such as Malaysia and the European region, the use of blockchain is already very popular in Islamic finance. Data from the Dinar Standard 2018 Islamic FinTech Report states that according to the report, around 70 percent of Islamic fintech companies globally are focused on facilitating business and consumer financing through ECF equity crowdfunding and P2P lending. In this area, Bank Negara Malaysia launched the Investment Account 
Platform (IAP), an Islamic crowdfunding platform for the small and medium business sector(Fund, 2020)

Thus, this study is interested in discussing further how blockchain fintech can strengthen Islamic banking financial services in Indonesia. This study aims to provide an overview that fintech is very helpful in making financial services in Islamic banking wider, more flexible, safe, and transparent. Fintech in Islamic financial services must be the focus in order to continue to create an ever increasing Islamic financial market and provide evidence of its existence not only having products that have their own characteristics compared to conventional ones, but can also provide services using fintech to consumers so as to further strengthen services that prioritize digitization through blockchain technology.

\section{Literature Review}

\section{Islamic Financial Technology (Fintech)}

Prior to 2016, fintech in the Islamic finance sector was mostly in the form of crowdfunding platforms. Several outstanding achievements were recorded in 2016 such as the introduction of Islamic robo-advisor and Islamic Account Platform (IAP). There are also other fintech initiatives in Islamic finance launched or announced in 2016 such as the Islamic Fintech Alliance (IFT Alliance), Islamic Fintech Hub and Islamic Peer-toPeer (P2P) financing.(Dar \& Azmi, 2017).

Several fintech applications that have been present in Indonesia such as Goolive exists as a digital platform that aims to synergize agriculture and all the potential associated with it to produce high quality agricultural products that are safe, healthy and halal (halal according to sharia). Goolive enthusiastically educates the public, especially young people from various educational backgrounds, to work together to regenerate the pride and understanding that Indonesia is an agricultural and maritime country. This peer-to-peer lending company is also relatively new and has a small number of employees(Firmansyah et al., 2019).

NATURAL Sharia Technology is a Fintech technology startup sector that raises small and medium enterprises (SME) funding, with a major focus on the fast-growing sharia segment. As an Islamic Fintech aggregator, ALAMI helps SMEs to get funding from Islamic banks. This company targets to facilitate financing of up to Rp 100 billion to SMEs by the end of 2018 (Firmansyah et al., 2019). 


\section{Rahmayati}

Strengthening Islamic Banking Services In Indonesia Through Blockchain Technology: The ANPSTEP Approach

Qasir is a free cashier application that helps merchants to record sales, manage products, monitor stock and view sales reports. Qasir is available on two platforms, namely web and mobile applications. For mobile applications, Qasir is available for the Android operating system. In early 2018, Qasir began developing a feature that connects users with financial institutions to get loans (Firmansyah et al., 2019).

Initially, fintech was just borrowing money, as regulated in POJK number 77 / POJK.01 / 2016 concerning Information Technology-Based Borrowing and Lending. In the end, however, Bank Indonesia expanded the scope of fintech. This is because Bank Indonesia has a view that financial innovation that is efficient, safe, smooth and reliable will be able to support economic growth in Indonesia. This further strengthens the bank's performance in providing services to customers through the financial technology information system. In line with the above opinion, financial technology is considered to be an important factor in encouraging Indonesian finances. Fintech currently has many functions that are not only as an online financial transaction service. Research results from the Indonesian FinTech Association report that currently fintech companies in Indonesia are still dominated by payment companies (44 percent), aggregators (15 percent), financing (15 percent), personal and corporate financial planners (10 percent), crowdfunding. ( 8 percent) and others (8 percent)(Baidhowi, 2018).

The potential of the fintech market in Islamic finance is enormous because the industry is very new and largely untapped. The digital revolution is driving customer demand for financial services that are innovative, convenient, efficient and cost-effective. It is estimated that by 2020 there will be between 2 and 3 billion new consumers who will enter the digital finance space and $80 \%$ of these new consumers will be Muslim. This provides significant opportunities for fintech in Islamic finance. Strong awareness among Islamic finance stakeholders, encouragement from high-ranking officials of the monetary authority and a facilitative regulatory environment in the main Islamic financial market will play a major role in driving fintech innovation in Islamic finance.(Dar \& Azmi, 2017).

Fintech is one of the digital financial service technology innovations that is allowed in Islam because it brings enormous benefits and problems to society. The presence of fintech is an alternative solution for the creation of easier, faster and more efficient Islamic financial transactions. In addition, sooner or later, with the potential and wealth of natural resources, 
Indonesia has the opportunity to become the center of the world's halal industry which will promote halal food, halal fashion and halal tourism to achieve a Global Islamic Economy . The application of fintech in the sharia banking industry will make it easier and closer to business actors, especially micro, small and medium enterprises to access the sharia financial service products offered and apply for direct financing without having to come directly to branch offices. Such a model,(Fund, 2020).

In terms of financing the development of Islamic financial institutions that are more reliant on the real sector to meet the needs of the community, thus requiring a higher level of trust. For this reason, Islamic financial institutions must be able to take advantage of financial technology to accelerate the financing process. This technology is expected to facilitate services to customers in terms of financing products in Islamic banks in addition to shifting consumer preferences that affect consumer demand for innovation. Ease of internet access and the ability of internet network users to transact in real time have encouraged high expectations, especially regarding convenience, speed, lower costs, and ease of use of financial services(Fund, 2020).

\section{Blockchain}

Blockchain is a technology that originates from the idea of digital data that can be safely stored and transmitted without the risk of hacking or manipulation due to its decentralized nature. Traditionally, many aspects of our lives, including in the digital world, are controlled by an entity, so that we inevitably have to trust that entity. For example, banks, in order to be able to carry out various kinds of financial transactions such as transferring money, we must trust the bank that controls, runs and validates these transactions. Even though banks are essentially bound by laws and regulations, there is still a risk of entrusting financial transactions to one or a group of entities. The alternative is to make a direct transaction between two parties without a bank, but the risk is even greater, because there is no validation or security guarantee in direct transactions between two individuals. Blockchain technology appears to solve this problem, where data exchange or transactions are validated by the system before being permanently stored in a ledger in the form of a chain of interconnected data blocks but the storage is scattered (decentralized) and transferred by only one party (centralization). To make changes to the existing data, the data in other chains must also be changed. Each user can also check the validity of data at any time. This makes data on the blockchain nearly impossible to forge where data exchange or transactions are validated by the system before they are stored permanently in a ledger in the form of a chain of interrelated data blocks but the storage is distributed (decentralized) and transferred by only one party (centralization). To make changes to existing data, 


\section{Rahmayati}

Strengthening Islamic Banking Services In Indonesia Through Blockchain Technology: The ANPSTEP Approach

data in other chains must also be changed. Each user can also check the validity of data at any time. This makes data on the blockchain nearly impossible to forge where data exchange or transactions are validated by the system before they are stored permanently in a ledger in the form of a chain of interrelated data blocks but the storage is distributed (decentralized) and transferred by only one party (centralization). To make changes to the existing data, the data in other chains must also be changed. Each user can also check the validity of data at any time. This makes data on the blockchain nearly impossible to forge then the data on the other chains must also be changed. Each user can also check the validity of data at any time. This makes data on the blockchain nearly impossible to forge then the data on the other chains must also be changed. Each user can also check the validity of data at any time. This makes data on the blockchain nearly impossible to forge(Kumala, 2020).

In 2017, De la Torre and Torralba in their published financial reports revealed that, several investors identified various major technologies as the basis for the influence of technology; among others, artificial intelligence and its robotic implications, the internet of things (IoT), Blockchain and 3D and 4D printing. Some of these technologies will influence the future of key sectors of the economy and drive a revolution in venture capital. Most relevant to the financial industry are blockchain, and IoT, the basic technologies that make up fintech. Fintech usually refers to the technology start-up segment that affects sectors such as mobile payments, money transfers, loans, fundraising, and asset management.(Umar A. Oseni and S. Nazim Ali, 2019).

Blockchain is basically a transaction log with this new technology based on decentralized and encrypted information, it is possible to manage transaction records in a decentralized and comprehensive manner, creating trust between all parties, because any information can be verified however, the capacity to be able to record any transaction by means of safe, eliminating intermediaries, will soon make it possible to make cross-national payments at zero cost, and thus can be used to simplify the process of buying shares, enforcing contracts, smart contracts facilitating tax connections, and more (Umar A. Oseni and S. Nazim Ali, 2019).

Blockchain technology has several benefits and advantages due to its nature and the underlying technology structure. Blockchain is a collection of blocks that are linked on a peer to peer network where blocks are connected using cryptographic code that has no failure characteristics. Another important feature that blockchain has is digital technology which allows it to be implemented in a variety of applications. Another important feature of blockchain is transparency, blockchain transactions are traceable and visible to all blockchain users(Rabbani et al., 2020). 
Saudi Arabia's Al Rajhi Bank, which has the largest pool of Islamic banking assets globally, recently completed a cross-border money transfer using Ripple's blockchain technology. After completing its first cross-border blockchain deal, the bank now wants to use blockchain to serve its retail and corporate customers and is exploring how to integrate Blockchain technology to provide customers with money transfer solutions. Saudi Arabia is one of the leading countries for remittances and $\mathrm{Al}$ Rajhi has the largest network of money transfer centers in the country (over 200)(Partner et al., 2018).

\section{Methods}

This study uses primary data obtained through in-depth interviews and filling out questionnaires by the respondents. Respondents in this study varied from academics, fintech practitioners and Islamic financial institutions through purposive sampling technique. The data analysis method of this research is Analytical Network Process (ANP) with the cluster approach of Security, Transparency, Efficiency, Permanent (STEP). The cluster is used to identify, classify those that affect the outcome of the decision(Thomas L.aaty \& Luis G. Vargas, 2010). The analytical tool used by ANP with Super Decisions software. ANP was chosen in order to explain the factors model and decision making in the ANP application, namely to consider and validate empirical experiences.(Rusydiana, 2019).

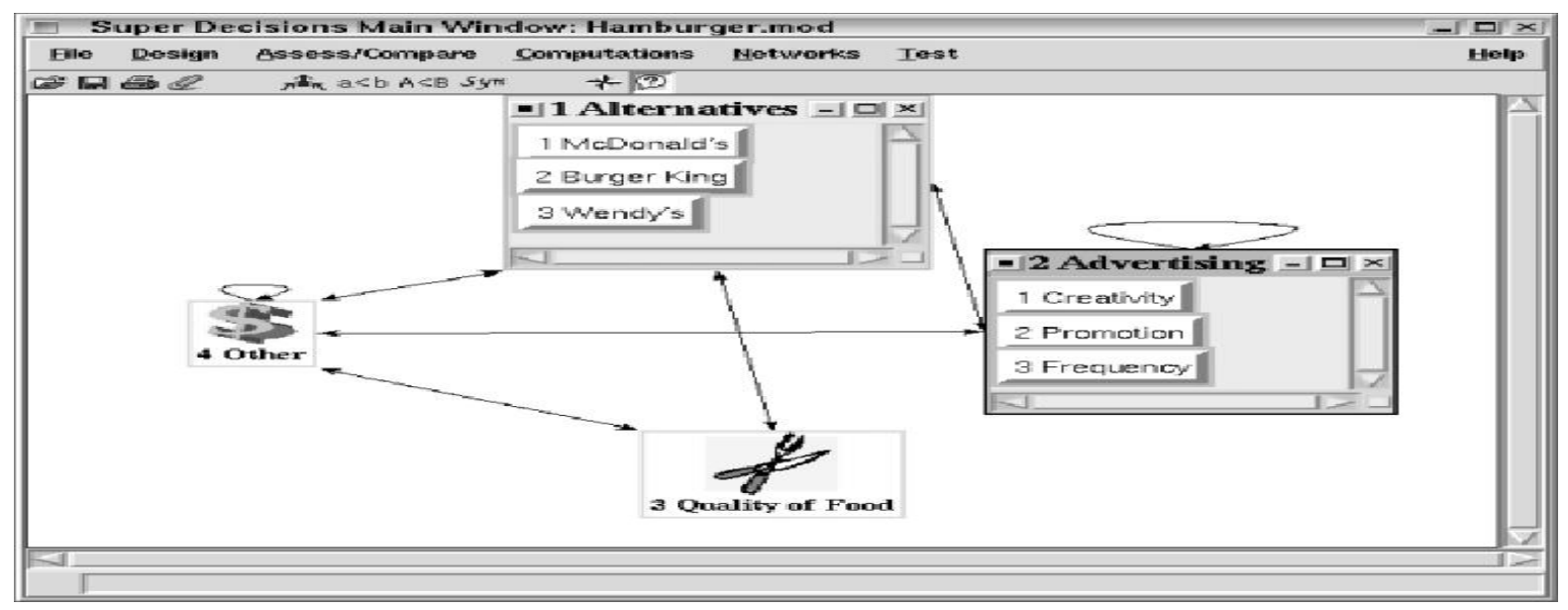

Figure 1. Super Decisions Main Window 


\section{Rahmayati}

Strengthening Islamic Banking Services In Indonesia Through Blockchain Technology: The ANPSTEP Approach

\section{Result and Discussion}

\section{Security}

Data security is one of the most valuable features of the blockchain. Therefore, Islamic banking companies can choose blockchain to properly secure their big data. Because of this, hackers, snoops and other cyber criminals cannot access the data stored on the blockchain in any way. Uniquely, blockchain is used in distributed storage software, and the data available on it is shared over a network of people. Thus, Islamic banking can manage its data without problems. Likewise, public services can also take great advantage of blockchain to secure publicly available data.

Islamic banking can apply the blockchain concept to reduce the possibility of financial fraud to some extent. That is, they can improve their users' financial information instantly. With the help of blockchain, banks can easily share, view and store digital information of their customers. The blockchain uses cryptographic encryption that secures every transaction, making it easier for banks to increase their overall security.

\section{Transparency}

Transparency is the openness of banks in providing information related to financial resource management activities to parties who are stakeholders. Transparency is the implementation of tasks and activities that are open to the public, starting from the policy process, planning, implementing, monitoring and controlling that are easily accessible to all parties who need such information.

The transparency provided by blockchain is that when using blockchain, data can be aggregated, can be collected, but is not owned by the collector, but remains with the data owner. data storage will be very safe when using blockchain because the data will be encrypted in one block first. After that, it is distributed to another block to be encrypted again. Blockchain technology can provide transparency and efficiency.for example, L / C (Letter of Credit). Transactions carried out by inter-state banks, in principle, must be checked between parties before going to the recipient, this of course takes time to transact, besides that there is also the possibility of fraud. Not to mention the costs that must be incurred. If you look at it, you will find the issue trust, time and costs. If all this time all data is connected to one server where all data depends on the IT division, blockchain technology allows all divisions to audit. So, each division has its own server which is tied together by blockchain so that it can detect data discrepancies or fraud 


\section{Efficiency}

Blockchain technology has the potential to significantly reduce costs and time in cross-border banking transactions, improve bank efficiency but put pressure on non-service or fee-based income. Blockchain technology makes cross-border transactions faster and cheaper. This can be a positive credit for the bank because it increases efficiency and becomes a negative credit because it reduces fee based income. Blockchain has the potential to substantially change the way various kinds of financial services are run. Banks can make significant use of the development and implementation of blockchain technology in terms of increased efficiency, cost savings and risk reduction.

The blockchain stores transactions digitally, so there is no possibility of errors in transaction figures. So, it will help banks to make their financial books directly. They must take a printout of the transaction and attach it to a financial book to create a balance sheet. So we can say that blockchain makes the record keeping process very efficient and stable for banks. Blockchain has the potential to change the execution of financial services provided. Banks can benefit significantly from the development and implementation of this technology in terms of efficiency, cost savings and reduced risk.Blockchaincan serve financial transactions anytime and anywhere without any time and space restrictions. With this, business processes can be carried out anywhere and anytime. For example, RTGS transactions have a certain time limit and cannot be done on holidays but blockchain can be a solution to this. Of course this will greatly provide time efficiency in the world of banking financial services.

\section{Permanent}

Companies or institutions that use technologyblockchain, the data that has been saved cannot be changed. Therefore, the data is guaranteed to remain safe. Although the data cannot be changed, it can still be updated if there is an update. On the blockchain the person's identity remains hidden because the records are stored in the form of a scripting language, no one can change the person's personal details. Also, they cannot increase the transaction flow.

\section{ANP-Cluster Analysis}

Based on the results of literature and interviews conducted in determining the cluster of this research, which has several cluster approaches, including in the table below: 


\section{Rahmayati}

Strengthening Islamic Banking Services In Indonesia Through Blockchain Technology: The ANPSTEP Approach

Table 1. Cluster and Node

\begin{tabular}{|l|l|}
\hline \multicolumn{1}{|c|}{ ClUSTER } & \multicolumn{1}{c|}{ NODE } \\
\hline Security & Audit Trail \\
\hline & Traceability \\
\hline & Real Time \\
\hline Transparancy & Peerto Peer \\
\hline & Reliable \\
\hline Efficiency & Cost \\
\hline & Time \\
\hline Permanent & Imast \\
\hline
\end{tabular}

20. Super Decisions Main Window: STEP 2.sdmod

File Design Assess/Compare Computations Networks Help

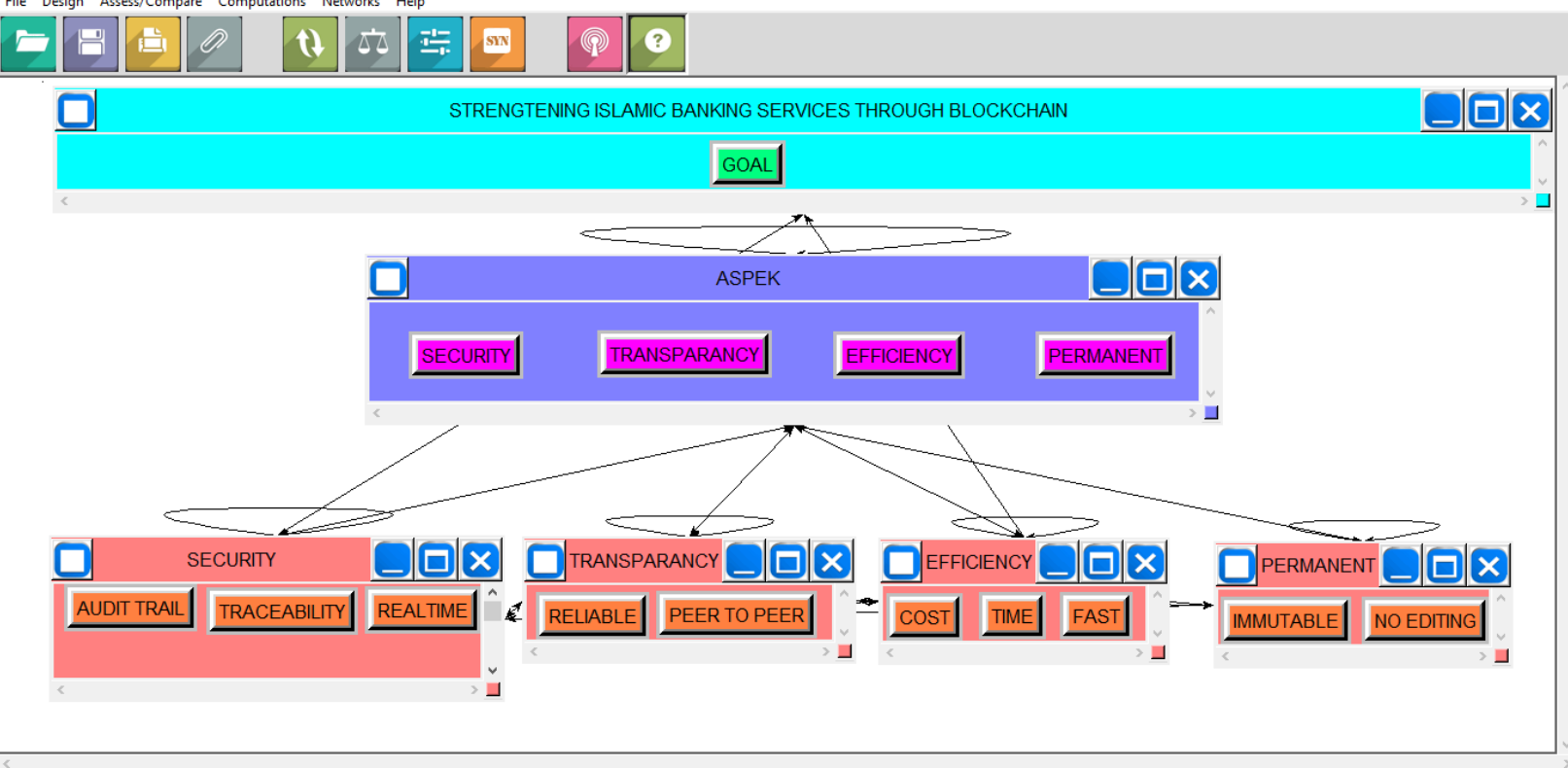

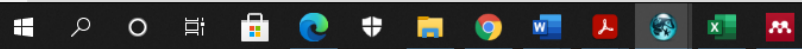

Figure 2. ANP

The analysis was carried out on the four clusters so as to produce an analysis of the linkages and feed back of each cluster to obtain answers through interviews conducted. From the interview, the respondents agreed on the use of blockchain technology in financial services in Islamic banking to strengthen Islamic banking services. These are summarized in the four clusters with each of the nodes that have been discussed and from the literature of interest in this study.

After A pairiwise comparison of each feed back cluster and node is performed, the following results are obtained: 
Tabel 2. Result Conclusion

\begin{tabular}{|l|c|}
\hline Security & $68 \%$ \\
\hline Transparency & $52 \%$ \\
\hline Efficiency & $82 \%$ \\
\hline Permanent & $42 \%$ \\
\hline
\end{tabular}

From the summary table above shows that the cluster that gives greater results is efficiency which is the basis that due to the nature of blockchain it provides advantages for banks in terms of costs, time, and speed of services provided in real time. Then in terms of security generated by blockchain, it proves that the data that has been blocked through blockchain cryptography really provides the security strength that is needed in financial services in banking in the long term, namely so that the results of the examination do not produce bad findings for the bank because the bank prioritizes trust and integrity. high. Because it provides high security, the blockchain also provides the required information in a transparent, transparent manner for all service users without taking sides with either party, given is an equal advantage and benefit for all parties. This transparency is supported by other characteristics of the blockchain, namely that it is permanent so that it cannot be edited to provide unilateral benefits.

\section{Conclusion}

Result research proves that the use of blockchain technology is needed to strengthen and support financial services in Islamic banking. With this study of the blockchain as proof that the four cluster approaches and each of their derivatives prove that blockchain can provide efficiency in terms of both cost, time, and speed in Islamic banking services. Then in terms of security provided by blockchain, which is the strength of blockchain in presenting information, the data needed by its users transparently because the data has been stored through cryptographic blocks that cannot be changed at any time because these characteristics are the virtue of blockchain for financial companies such as banking. .

\section{References}

Anikina, ID, Gukova, AV, Golodova, AA, \& Chekalkina, AA (2016). Methodological aspects of prioritization of financial tools for stimulation of innovative activities. European Research 


\section{Rahmayati}

Strengthening Islamic Banking Services In Indonesia Through Blockchain Technology: The ANPSTEP Approach

Studies Journal, 19 (2 Special Issue), 100-112. https://doi.org/10.35808/ersj/525

Baidhowi, B. (2018). Sharia Banking Opportunities and Challenges in the Digital Era. 192 (Icils), 157161. https://doi.org/10.2991/icils-18.2018.30

Dar, PH, \& Azmi, DS (2017). Islamic Finance in the Digital Age: FinTech Revolution. Global Islamic Finance Report, 282-290.

Firmansyah, EA, Anwar, M., \& Padjadjaran, U. (2019). ISLAMIC FINANCIAL TECHNOLOGY (FINTECH): ITS CHALLENGES AND Profile of the Islamic Fintech Firms The six Islamic Fintech firms participating in this research are the firms headquartered in Indonesia. 216 (Assdg 2018), 52-58.

Fund, IM (2020). Selected issues (Issue 20, pp. 0-20). Washington DC.

Irma Muzdalifa, Inayah Aulia Rahma, BGN (2018). (Islamic Finance Approach). Masharif Al-Sharia Journal: Journal of Islamic Economics and Banking, 3 (1).

Kumala, MY \& D. (2020). Blockchain Technology for Transparency and Security in the Digital Age. 6. http://repository.unmuha.ac.id/xmlui/handle/123456789/579

Partner, S., Partner, E., \& Partners, MS (2018). Report 2018 EXCLUSIVE PARTNER.

Rabbani, MR, Khan, S., \& Thalassinos, EI (2020). FinTech, Blockchain and Islamic Finance: An Extensive Literature Review. VIII (2), 65-86.

Rusydiana, A. (2019). How to Develop Sharia Fintech Industry in Indonesia? Interpretive Structural Model (ISM) approach. Al-Muzara'ah, 6 (2), 117-128. https://doi.org/10.29244/jam.6.2.117128

Saksonova, S., \& Kuzmina-Merlino, I. (2017). Fintech as financial innovation - The possibilities and problems of implementation. European Research Studies Journal, 20 (3), 961-973. https://doi.org/10.35808/ersj/757

Susanne Chishti \& Janos Barberis. (2016). The FINTECH Book. In The Fintech Book.

Thomas L.aaty \& Luis G. Vargas. (2010). International Series in Operations Research \& Management Science Introduction. In FS Hillier (Ed.), Customer Satisfaction Evaluation: Methods for 
Measuring and Implementing Service Quality (Second Edi, Vol. 139). Springer. file: /// C: /Users/HP/Downloads/qdoc.tips_saaty-vargas-models-methods-concepts-applications-.pdf

Umar A. Oseni and S. Nazim Ali. (2019). FINTECH IN ISLAMIC FINANCE theory and Practice (Umar A. Oseni and S. Nazim Ali (ed.); First publ). Routledge London and New York.

Wibowo, B. (2016). Analysis of fintech regulations in building the economy in Indonesia. Journal of Master of Electrical Engineering at Mercu Buana University, 1-9.

Wulandari, PA (2017). Swot Analysis of the Development of Financial Technology in Indonesia. Proceedings of the ASBIS National Seminar, 376-383. 